\title{
PREPARASI DAN KARAKTERISASI MEMBRAN SERAT NANO POLIVINIL ALKOHOL/GELATIN DENGAN ANTIBIOTIKA TOPIKAL MENGGUNAKAN METODE ELECTROSPINNING
}

\author{
PREPARATION AND CHARACTERIZATION OF POLYVINYL \\ ALCOHOL/GELATIN NANOFIBROUS MEMBRANES WITH TOPICAL \\ ANTIBIOTICS BY ELECTROSPINNING METHOD
}

\author{
Theresia Mutia, Eva Novarini, RR. Srie Gustiani \\ Balai Besar Tekstil, Jalan Jenderal Ahmad Yani No. 390 Bandung 40272 \\ Telp. (022) 7206214, 7206215, Fax. (022) 7271288 \\ E-mail: bbt@kemenperin.go.id
}

Tanggal diterima: 8 Januari 2020, direvisi: 14 Desember 2020, disetujui terbit: 16 Desember 2020

\begin{abstract}
ABSTRAK
Pada penelitian ini dilakukan proses electrospinning membran serat nano dari polivinil alkohol (PVA) dan gelatin dengan penambahan antibiotika topikal (Bacitracin dan Neomycin). Membran serat nano ini berpotensi untuk dijadikan sebagai produk pembalut luka atau media penghantar obat. Membran serat nano paling optimum diperoleh pada konsentrasi larutan PVA 10\% (w/w) dan gelatin 5\% (w/w) dengan rasio komposisi berat 70/30. Kondisi ini menghasilkan serat nano dengan ukuran $\leq 300 \mathrm{~nm}$ dan keseragaman serat yang cukup baik berdasarkan analisis morfologi menggunakan SEM. Penambahan antibiotika topikal dilakukan pada kondisi pembuatan membran serat nano paling optimum. Berdasarkan hasil analisis gugus fungsi menggunakan FTIR, pada grafik terlihat gabungan antara spektra PVA, gelatin, dan antibiotika topikal. Hal ini menandakan adanya interaksi antara molekul PVA, gelatin, dengan antibiotika topikal.
\end{abstract}

Kata kunci: electrospinning, serat nano, PVA, gelatin, antibiotika topikal

\section{ABSTRACT}

Nanofibrous membrane of PVA and gelatin with the addition of topical antibiotics (Bacitracin and Neomycin) were fabricated in this research by electrospinning process. The nanofibrous membrane has the potential to be used for wound dressing products or drug delivery media. The most optimum nanofibrous membrane was obtained from solutions of $10 \%$ PVA $(w / w)$ and $5 \%$ gelatin $(w / w)$ using weight composition ratio 70/30. This condition produced nanofibers with a size of $\leq 300 \mathrm{~nm}$ and a fairly good uniformities of fibers based on morphological analysis using SEM. The addition of topical antibiotics is carried out at the optimum condition of nanofibrous membrane fabrication. Based on the functional groups analysis using FTIR, the graphic showed a combination of PVA, gelatin, and topical antibiotics spectras. This condition suggests that interaction between PVA, gelatin, and topical antibiotics molecules has indeed occurred.

Keywords: electrospinning, nanofiber, PVA, gelatin, topical antibiotics

\section{PENDAHULUAN}

Teknologi electrospinning pada dasarnya telah berkembang sejak lama. Paten pertama mengenai teknologi ini diperoleh oleh Formhals dkk pada tahun 1934 untuk alat pembuat filamen buatan dari material selulosa asetat. ${ }^{1}$ Prinsip kerja proses electrospinning adalah mengaliri cairan polimer (dalam bentuk larutan atau lelehan) dengan medan listrik bertegangan tinggi hingga menghasilkan untaian jet yang keluar secara kontinyu dari nosel menuju grounded kolektor yang memiliki muatan listrik berlawanan. ${ }^{2}$ Keluaran dari proses ini adalah serat polimer dengan ukuran diameter dalam kisaran sub mikron. ${ }^{3}$
Membran serat nano hasil proses electrospinning memiliki sifat unik, seperti rasio area permukaan per unit massa yang besar, porositas, dan permeabilitas gas yang tinggi serta performa mekanik yang sangat baik. Sifat-sifat ini sangat berguna untuk berbagai aplikasi, seperti filtrasi (udara dan cairan), sensor kimia dan optik, media penyimpanan hidrogen, bagian komponen pada sel bahan bakar, rekayasa jaringan, serta bahan baku biomedis., ${ }^{3,4}$ Meski hampir sebagian besar riset masih menggunakan polimer sintetik untuk bahan baku electrospinning serat nano, namun kini penggunaan polimer alam (biomaterial) mulai mendapatkan banyak perhatian. Sebagai contoh 
adalah penggunaan kolagen, DNA, alginat, kitosan, fibrinogen, asam hialuronat, gelatin, serta polisakarida kompleks, dan protein lainnya dari bakteri maupun tanaman. ${ }^{3,6}$

Gelatin adalah polimer alam yang peredarannya telah mendapatkan persetujuan dari FDA (Food and Drug Administration). Gelatin merupakan kolagen yang terhidrolisis secara parsial dan memiliki sifat biodegradabel, non toksik, biokompatibel, murah dan mudah didapatkan, sehingga lingkup penggunaannya pun sangat luas terutama pada industri makanan dan medis. ${ }^{7}$ Risetriset mengenai electrospinning gelatin serta aplikasinya dalam bidang medis, di antaranya adalah komposit PCL (policaprolakton)/gelatin untuk aplikasi pada perancah rekayasa jaringan, ${ }^{8,9,10,11}$ serat nano gelatin untuk media penghantar obat (drug delivery) ${ }^{7,12,13}$ dan membantu proliferasi serta migrasi sel otot dan endotel, ${ }^{14}$ electrospinning gelatin/gliserol yang diikatsilangkan dengan uap glutaraldehid untuk aplikasi rekayasa jaringan dan pembalut luka, ${ }^{15}$ komposit gelatin/ZnO nanopartikel dengan antibiotik Cefazolin untuk perawatan luka pasca operasi, ${ }^{16}$ serta serat nano PLGA (Poly (lactic-coglycolic acid))/gelatin untuk perancah rekayasa jaringan pada tulang ${ }^{17,18}$ dan media penghantar obat. ${ }^{19}$

Berdasarkan berbagai riset mengenai pembuatan serat nano gelatin menggunakan teknologi electrospinning, diketahui bahwa peningkatan konsentrasi gelatin akan menaikkan nilai konduktivitas listriknya, namun berbanding terbalik dengan menurunnya tegangan permukaan seiring meningkatnya konsentrasi gelatin pada larutan pintal. Karakteristik viskositas larutan mengindikasikan kualitas spinnability, ukuran, dan morfologi dari struktur membran serat nano. Voltase tegangan listrik dan laju alir larutan (feed rate) yang digunakan akan berpengaruh pula pada pembentukan beads, homogenitas, dan diameter seratnya. ${ }^{6,20,21}$

Dari penelitian terdahulu, diketahui bahwa komposit berskala nano yang terbuat dari campuran alginat dan gelatin telah lolos uji preklinis dan dapat digunakan sebagai pembalut luka serta media penyampaian obat topikal. Produk tersebut diketahui dapat mempercepat penyembuhan luka dan tidak menyebabkan iritasi. ${ }^{22,23,24}$ Pada penelitian lanjutan ini, dilakukan pembuatan komposit PVA (polivinil alkohol)/gelatin berupa membran atau webs (lapisan jaringan tipis) melalui proses electrospinning dengan penambahan antibiotika topikal Bacitracin dan Neomycin. Variasi percobaan dilakukan pada konsentrasi gelatin dan polivinil alkohol dengan parameter tetap pada jarak antara ujung nosel larutan (tip) dengan grounded kolektor, laju alir larutan, dan voltase tegangan listrik yang digunakan.
Polivinil alkohol digunakan untuk mengatasi keterbatasan dalam aplikasi polimer alam pada proses electrospinning. Polimer alam seperti halnya gelatin, memiliki efisiensi dan keberulangan (reproducibility) rendah pada proses electrospinning serta tantangan dalam memperoleh serat dengan keseragaman tinggi. Hal ini disebabkan oleh sangat berbedanya konformasi rantai molekul, respon hidrodinamis, dan gaya tolak menolak di antara polianion dalam polimer alam. ${ }^{25}$ Untuk mengatasi hal tersebut, mencampurkan polimer alam dengan polimer sintetik yang non toksik, larut dalam air, dan biokompatibel, seperti polivinil alkohol adalah salah satu solusi, karena PVA dapat mengurangi gaya tolak menolak antar muatan pada larutan polimer alam sehingga serat dapat dipintal. ${ }^{26} \mathrm{Pada}$ komposisi dan titik tertentu, penambahan PVA pada gelatin dapat meningkatkan sifat mekaniknya. ${ }^{27}$ Selain sifatnya yang larut dalam air, murah dan mudah didapatkan, polivinil alkohol juga memiliki kestabilan secara kimiawi dan temperatur, tidak mudah terdegradasi pada berbagai kondisi fisiologis dan yang terpenting adalah sifatnya yang biokompatibel dan non toksik sehingga tidak akan menyebabkan toksisitas maupun gangguan stimulasi pada jaringan sel di dalam tubuh. ${ }^{3,27}$

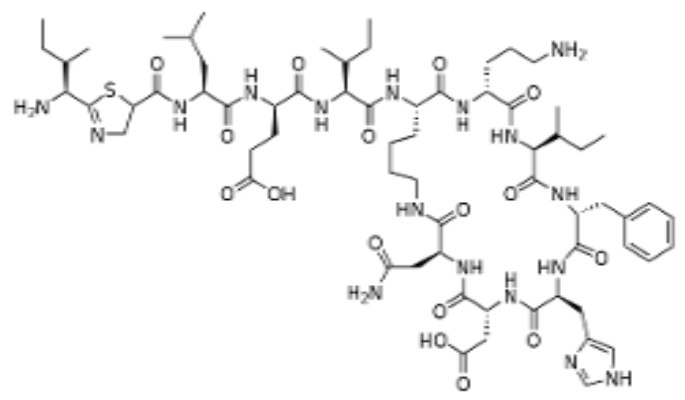

Bacitracin

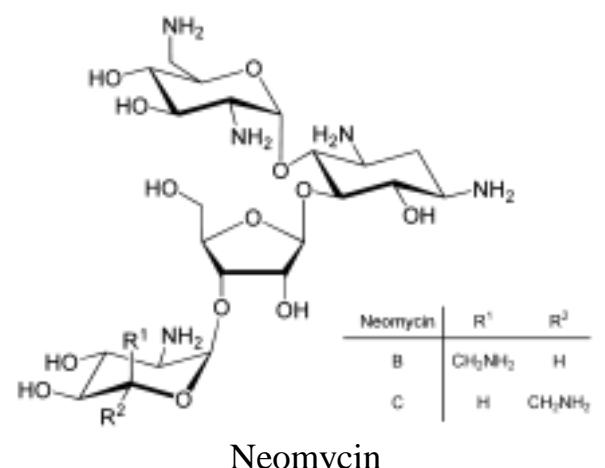

Gambar 1. Struktur molekul Bacitracin dan Neomycin

Luka terbuka pada umumnya berpotensi untuk berkembang menjadi infeksi. Oleh karena itu, aplikasi antibiotika topikal dipandang perlu untuk menambah keefektifan/efikasi suatu pembalut luka. 
Antibiotika topikal yang digunakan pada penelitian ini adalah jenis Bacitracin dan Neomycin. Keduanya merupakan antibiotika topikal penting untuk penanganan masalah kulit. Struktur Bacitracin dan Neomycin dapat dilihat pada Gambar 1. Bacitracin adalah antibiotika campuran dari polipeptida siklik $\left(\mathrm{C}_{66} \mathrm{H}_{103} \mathrm{~N}_{17} \mathrm{O}_{16} \mathrm{~S}\right)$. Bacitracin mengganggu sintesis dinding sel bakteri kokus gram positif, seperti Staphylococcus dan Streptococcus. Bacitracin topikal efektif untuk pengobatan infeksi bakteri superfisial pada kulit. ${ }^{28}$ Neomycin adalah antibiotika golongan aminoglikosida topikal yang sering digunakan untuk mengobati infeksi akibat bakteri gram negatif (Escherichia coli), dengan memberi efek membunuh bakteri dengan mengganggu sintesis protein. Obat ini sering digunakan sebagai profilaksis infeksi yang disebabkan oleh abrasi superfisial, terluka, atau luka bakar. . $^{28,29,30}$

Dalam dunia perdagangan, serat nano adalah serat dengan diameter kurang dari $500 \mathrm{~nm}$, dan umumnya serat nano yang diperdagangkan memiliki kisaran ukuran $50 \mathrm{~nm}-300 \mathrm{~nm} \cdot{ }^{31}$ Pembalut luka dari serat nano umumnya memiliki ukuran pori antara $500 \mathrm{~nm}$ hingga $1 \mu \mathrm{m}$. Nilai ini memadai untuk melindungi luka dari penetrasi bakteri dan juga cukup memiliki luas permukaan yang tinggi, yaitu pada kisaran 5 hingga $100 \mathrm{~m}^{2} / \mathrm{g}$ yang cukup efisien untuk penyerapan cairan yang berasal dari luka. ${ }^{32,33}$ Pada penelitian ini, dilakukan percobaan pembuatan membran serat nano PVA/gelatin dan membran PVA/gelatin/antibiotika dengan target ukuran $\leq 300 \mathrm{~nm}$. Membran selanjutnya dikarakterisasi menggunakan scanning electron microscope (SEM) dan Fourier transform infrared spectroscopy (FTIR) untuk mengetahui morfologi membran, diameter serat, keseragaman, dan struktur serta perubahan ikatan kimia dan gugus fungsinya.

\section{METODE \\ Bahan}

Bahan yang digunakan adalah gelatin, polivinil alkohol, asam asetat glasial, alkohol, serta antibiotika topikal jenis Bacitracin dan Neomycin. Seluruh bahan kimia digunakan langsung tanpa purifikasi lebih lanjut. Persiapan pembuatan larutan pintal seluruhnya menggunakan akuades.

\section{Peralatan}

Peralatan yang digunakan adalah peralatan gelas lengkap, neraca analitis, magnetic stirrer, syringe $10 \mathrm{ml}$, viscometer merek Brookfield, conductivity meter merek HACH-German, mesin electrospinning merek Eltexindo, scanning electron microscope merek JEOL JSM-6360 LA, dan Fourier transform infrared spectroscopy (FTIR) merek Perkin Elmer Spectrum One.

\section{Electrospinning}

\section{- Persiapan larutan spinning}

Sebelum proses electrospinning, dilakukan pelarutan untuk masing-masing polimer. Gelatin dilarutkan pada temperatur kamar dalam campuran asam asetat glasial dan akuades, kemudian diaduk menggunakan magnetic stirrer selama 2 jam hingga terlarut sempurna. PVA dilarutkan dalam akuades pada temperatur $80^{\circ} \mathrm{C}$ dengan pengadukan konstan menggunakan magnetic stirrer selama 2 jam, kemudian didinginkan hingga temperatur kamar sebelum digunakan untuk proses electrospinning. Konsentrasi akhir larutan gelatin adalah 5\% $(\mathrm{w} / \mathrm{w})$ sedangkan PVA $10 \% \quad(\mathrm{w} / \mathrm{w})$. Untuk pembuatan larutan pintal, larutan gelatin dan PVA dicampur dengan berbagai rasio untuk mendapatkan komposisi rasio yang paling optimum. Sebelum digunakan, campuran larutan pintal didiamkan terlebih dahulu selama 24 jam pada temperatur kamar.

- Pengukuran viskositas dan daya hantar listrik Viskositas larutan spinning PVA/gelatin diukur menggunakan alat viscometer, sedangkan daya hantar listriknya diukur menggunakan conductivity meter.

Tabel 1. Rasio komposisi larutan pintal PVA/gelatin

\begin{tabular}{ccc}
\hline Kode & \multicolumn{2}{c}{ Komposisi larutan pintal } \\
\cline { 2 - 3 } variasi & Gelatin 5\% & PVA 10\% \\
\hline A & 60 & 40 \\
\hline B & 50 & 50 \\
\hline C & 40 & 60 \\
\hline D & 30 & 70 \\
\hline E & 20 & 80 \\
\hline
\end{tabular}

- Proses electrospinning

Percobaan proses electrospinning dilakukan di mesin electrospinning pada temperatur kamar, menggunakan syringe $10 \mathrm{ml}$ dengan diameter dalam $0,838 \mathrm{~mm}$. Voltase tegangan listrik yang digunakan adalah $38 \mathrm{kV}$, jarak antara ujung tip nosel dengan grounded kolektor $10 \mathrm{~cm}$, dan laju alir larutan 0,4 ml/jam. Percobaan dilakukan dengan memvariasikan komposisi rasio larutan spinning PVA $10 \%$ dan gelatin 5\% sebagaimana yang dapat dilihat pada Tabel 1. Pada komposisi larutan spinning yang dinilai optimum, dilakukan penambahan antibiotika topikal Bacitracin dan Neomycin sesuai dengan dosis yang telah ditetapkan, yaitu Bacitracin sebanyak 400 IU per gram sediaan dan Neomycin sebanyak $5 \mathrm{mg}$ per gram sediaan. 


\section{Analisis gugus fungsi dan struktur mikro}

Keberhasilan electrospinning salah satunya dinilai dari terbentuknya ikatan antara PVA/gelatin dan PVA/gelatin/antibiotika yang akan dibuktikan melalui analisis gugus fungsi menggunakan FTIR. Untuk mengetahui struktur mikro membran seperti morfologi, diameter, dan keseragaman seratnya, dilakukan pengamatan menggunakan scanning electron microscope (SEM).

\section{HASIL DAN PEMBAHASAN}

Bentuk dan ukuran serat nano yang dihasilkan pada proses electrospinning selain ditentukan oleh sifat larutan (konsentrasi, viskositas, daya hantar listrik, tegangan permukaan, berat molekul polimer, momen dipol, dan konstanta dielektrik), juga dipengaruhi oleh variabel terkendali dan parameter ambien. Variabel terkendali adalah laju alir, kuat medan listrik/voltase tegangan, jarak antara ujung tip nosel dengan grounded kolektor, bentuk jarum syringe, serta komposisi dan geometri kolektor. Parameter ambien adalah temperatur, kelembaban udara ruangan, serta kecepatan udara dalam ruang electrospinning. ${ }^{6,32,34}$

Berdasarkan penelitian terdahulu, ${ }^{32,35,36}$ parameter yang berpengaruh pada proses electrospinning gelatin untuk mendapatkan hasil yang telah dianggap optimum, di antaranya adalah voltase tegangan listrik yang digunakan, ukuran syringe, jarak antara ujung tip nosel dengan grounded kolektor, laju alir larutan, dan temperaturnya. Selain itu, telah diketahui juga bahwa penggunaan gelatin dengan konsentrasi yang terlalu tinggi akan menyebabkan terbentuknya banyak beads. Beads tersebut merupakan larutan spinning yang tidak berhasil menjadi untaian jet yang dapat ditarik oleh medan listrik yang berlawanan, hal ini kemungkinan disebabkan oleh tidak seimbangnya kondisi larutan (konsentrasi, viskositas maupun daya hantar listrik) dan laju alir dengan voltase tegangan listrik yang digunakan. Pada percobaan yang telah dilakukan, untuk rasio konsentrasi gelatin 5\% paling tinggi sesuai Tabel 1 (PVA/gelatin rasio 20:80) terlihat bahwa banyak sekali beads yang terbentuk (Gambar 2). Dengan demikian, PVA/gelatin rasio 20:80 tidak digunakan dalam proses electrospinning selanjutnya.

Viskositas dan daya hantar listrik larutan electrospinning PVA/gelatin pada berbagai variasi komposisi dapat dilihat pada Gambar 3. Dari penelitian sebelumnya, ${ }^{35}$ diketahui bahwa viskositas larutan pintal PVA/gelatin akan meningkat setelah penyimpanan selama waktu tertentu dan kemudian akan mengalami penurunan. Pembentukan gel PVA/gelatin akan berlangsung sempurna setelah penyimpanan selama 24 jam, kemudian viskositas gel akan menurun akibat degradasi secara biologi oleh aktivitas mikroba. Pada penelitian ini, larutan pintal electrospinning langsung digunakan setelah penyimpanan selama 24 jam. Dari Gambar 3, terlihat bahwa terjadi perubahan pada viskositas seiring dengan perubahan rasio penggunaan PVA dan gelatin pada larutan. PVA terlihat lebih berperan dalam meningkatkan viskositas larutan pintal, terbukti dengan semakin tinggi rasio PVA dalam larutan maka viskositasnya akan semakin tinggi. Nilai viskositas ini akan menentukan kemudahan penarikan serat atau pembentukan untaian jet dari tip nosel menuju kolektor saat proses electrospinning berlangsung.

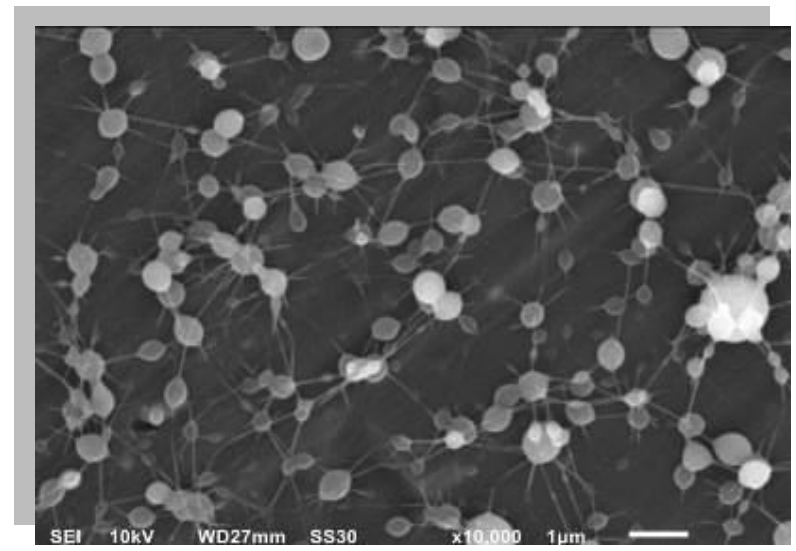

Gambar 2. Citra SEM struktur mikro serat hasil electrospinning PVA 10\%/gelatin 5\% rasio 2:8 (Pembesaran 10000 kali)

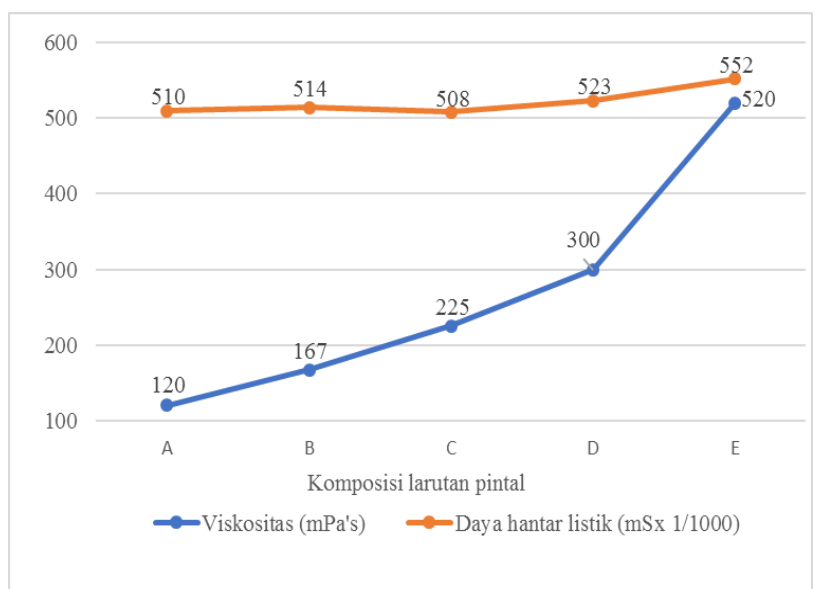

Gambar 3. Viskositas dan daya hantar listrik larutan pintal PVA/gelatin dengan berbagai rasio komposisi

Uji coba proses electrospinning dilakukan untuk mendapatkan komposisi larutan pintal paling optimum dengan variasi sesuai pada Tabel 1 dan parameter tetap, yaitu voltase tegangan listrik 38 $\mathrm{kV}$, nomor syringe 18 (diameter dalam $0,838 \mathrm{~mm}$ ), jarak tip dan kolektor $10 \mathrm{~cm}$, laju alir 0,4 ml/jam, serta temperatur $25^{\circ} \mathrm{C}$. Citra SEM hasil proses electrospinning untuk berbagai komposisi tersebut dapat dilihat pada Gambar 4 dan Gambar 5. Dari citra SEM membran serat nano tersebut, terlihat 
Preparasi dan Karakterisasi Membran Serat Nano Polivinil Alkohol/Gelatin dengan Antibiotika Topikal Menggunakan Metode Electrospinning (Theresia Mutia, dkk)

bahwa beads yang terbanyak terbentuk dari larutan PVA/gelatin dengan rasio 40/60, rasio ini merupakan rasio dengan konsentrasi gelatin $5 \%$ yang tertinggi dari komposisi yang lain. Semakin rendah rasio konsentrasi gelatin 5\% dalam larutan maka semakin sedikit beads yang terbentuk dan keseragaman serat pun semakin baik.

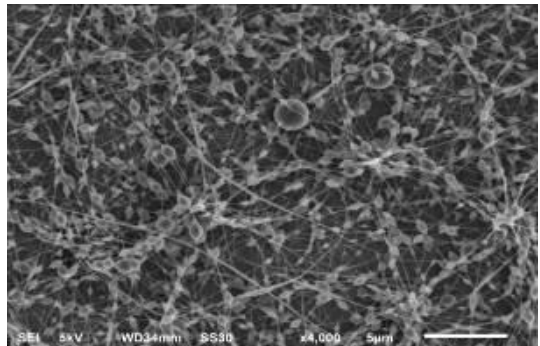

[rasio 40/60]

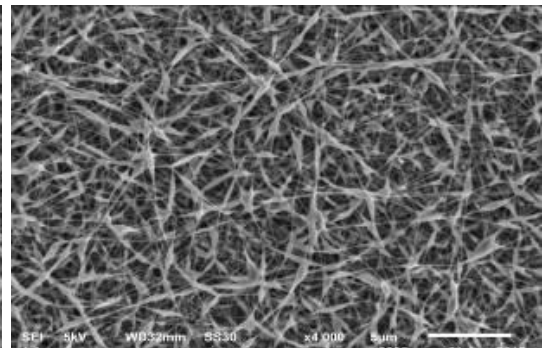

[rasio 50/50]

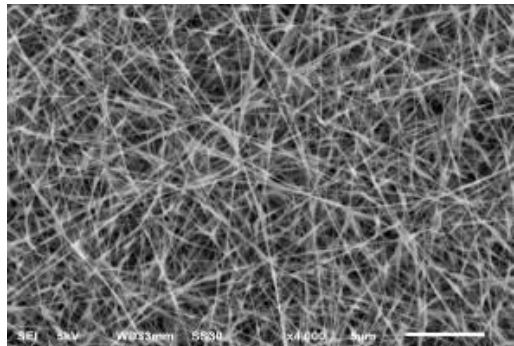

[rasio 60/40]

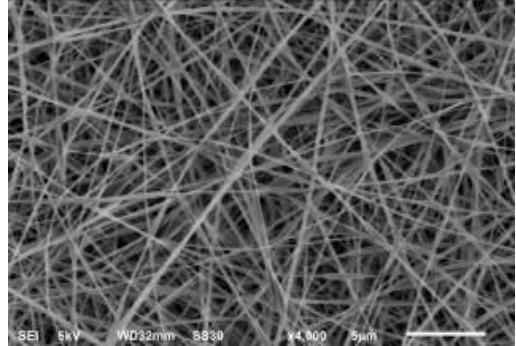

[rasio 70/30]

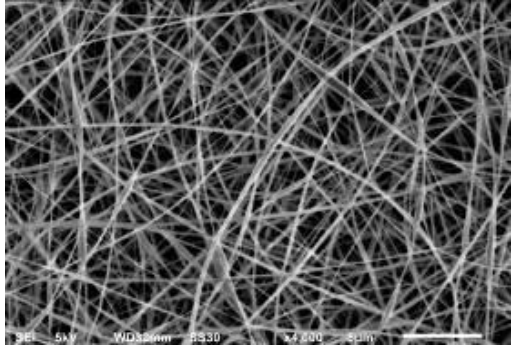

[rasio 80/20]

Gambar 4. Citra SEM struktur mikro serat hasil electrospinning PVA/gelatin (Pembesaran 4000 kali)

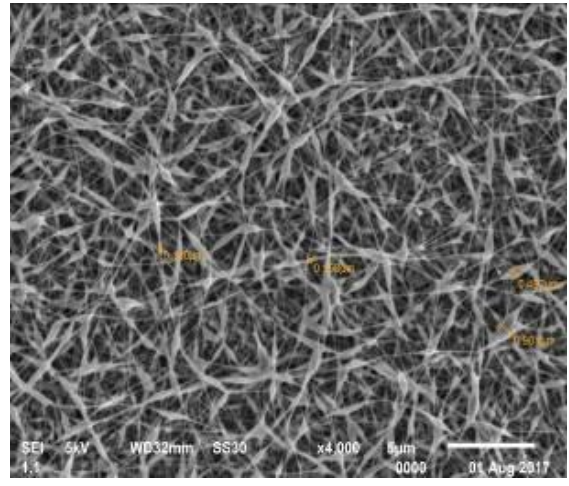

[rasio 50/50]

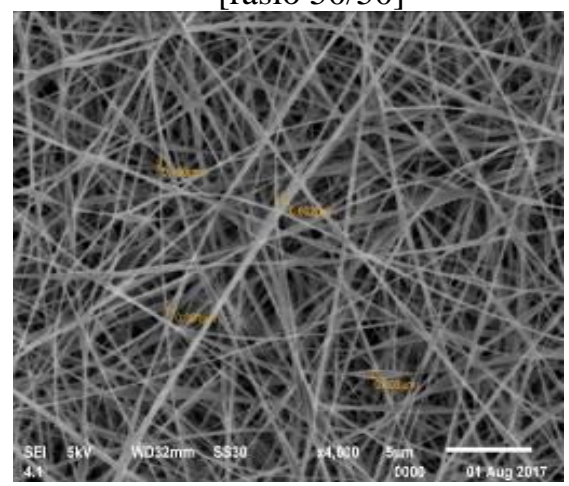

[rasio 70/30]

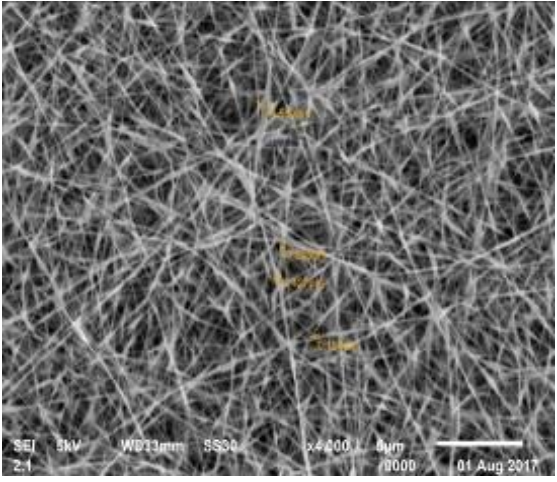

[rasio 60/40]

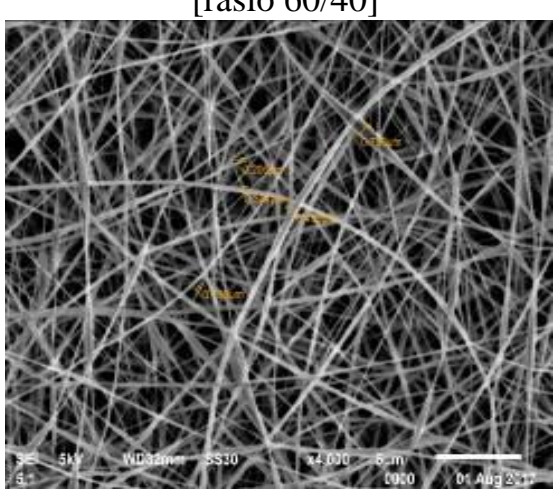

[rasio 80/20]

Gambar 5. Citra SEM ukuran serat hasil electrospinning PVA/gelatin (Pembesaran 4000 kali) 
Dari hasil percobaan yang telah dilakukan, larutan pintal PVA 10\%/gelatin 5\% dengan rasio komposisi 70/30 sebagian besar memiliki serat dengan ukuran $\leq 300 \mathrm{~nm}$, dengan demikian komposisi konsentrasi ini dianggap paling optimum untuk dibuat menjadi membran serat nano, di samping itu rasio tersebut juga mudah dalam proses penarikan seratnya dan memiliki keseragaman serat yang cukup baik jika dilihat dari citra SEM.

Larutan pintal PVA/gelatin dengan rasio komposisi 70/30 ini kemudian diberi tambahan antibiotika topikal Bacitracin sebanyak 400 IU per gram sediaan dan Neomycin sebanyak $5 \mathrm{mg}$ per gram sediaan. Membran serat nano yang dihasilkan ini dianggap cukup memadai, khususnya untuk keperluan tekstil medis, seperti produk pembalut luka atau media penghantar obat topikal. Gambar 6 menyajikan citra SEM membran serat nano PVA/gelatin tanpa dan dengan kandungan Bacitracin dan Neomycin. Pada gambar tersebut, teramati bahwa penambahan antibiotika Bacitracin dan Neomycin menyebabkan terjadinya perubahan morfologi, yaitu membran dengan penambahan antibiotika terlihat memiliki partikel-partikel menyerupai beads yang kemungkinan berisi partikel antibiotika. Partikel ini mengisi ronggarongga serat dan rongga antar serat sehingga membran serat tampak lebih padat.

Untuk mengetahui adanya reaksi yang terjadi atau perubahan gugus fungsi pada membran serat nano PVA/gelatin, dilakukan analisis menggunakan spektroskopi inframerah FTIR. Spektra FTIR dan puncak serapan panjang gelombang PVA, gelatin, dan PVA/gelatin dapat dilihat pada Gambar 7 dan Tabel 2.

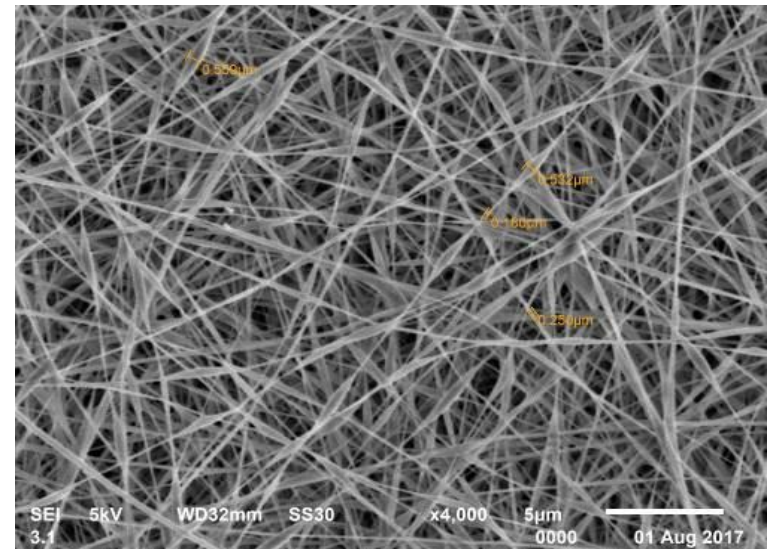

Tanpa penambahan antibiotika

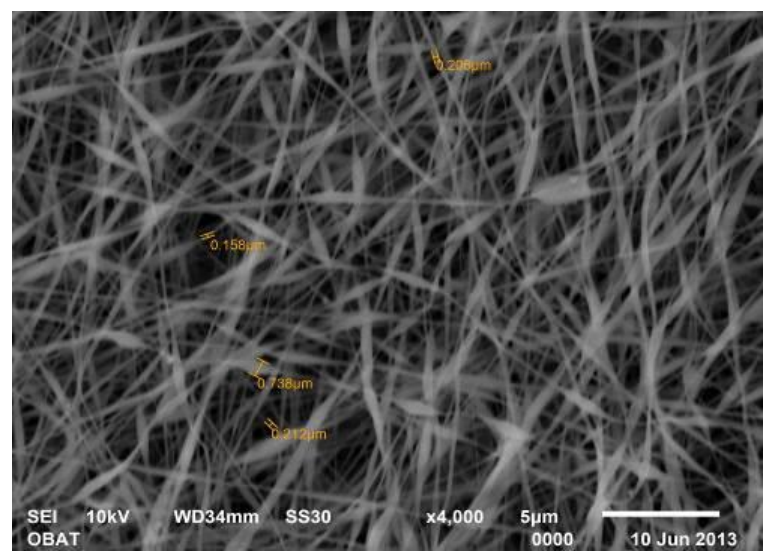

Dengan penambahan antibiotika

Gambar 6. Citra SEM struktur mikro serat hasil electrospinning PVA/gelatin rasio komposisi 70/30 (Pembesaran 4000 kali)

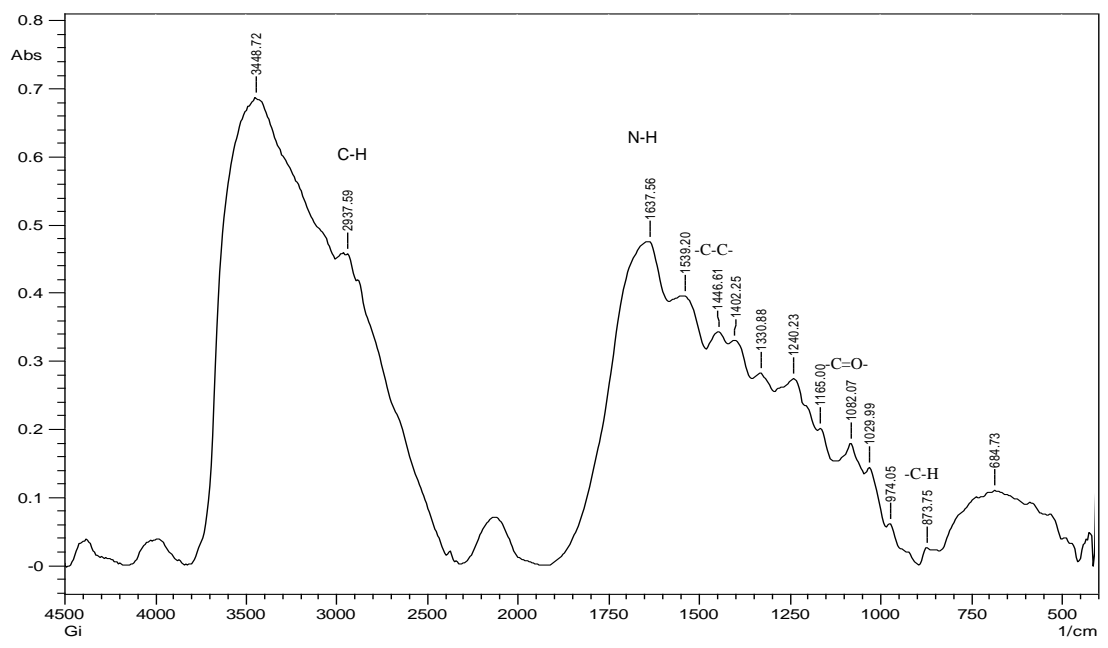

[a] 
Preparasi dan Karakterisasi Membran Serat Nano Polivinil Alkohol/Gelatin dengan Antibiotika Topikal Menggunakan Metode Electrospinning (Theresia Mutia, dkk)

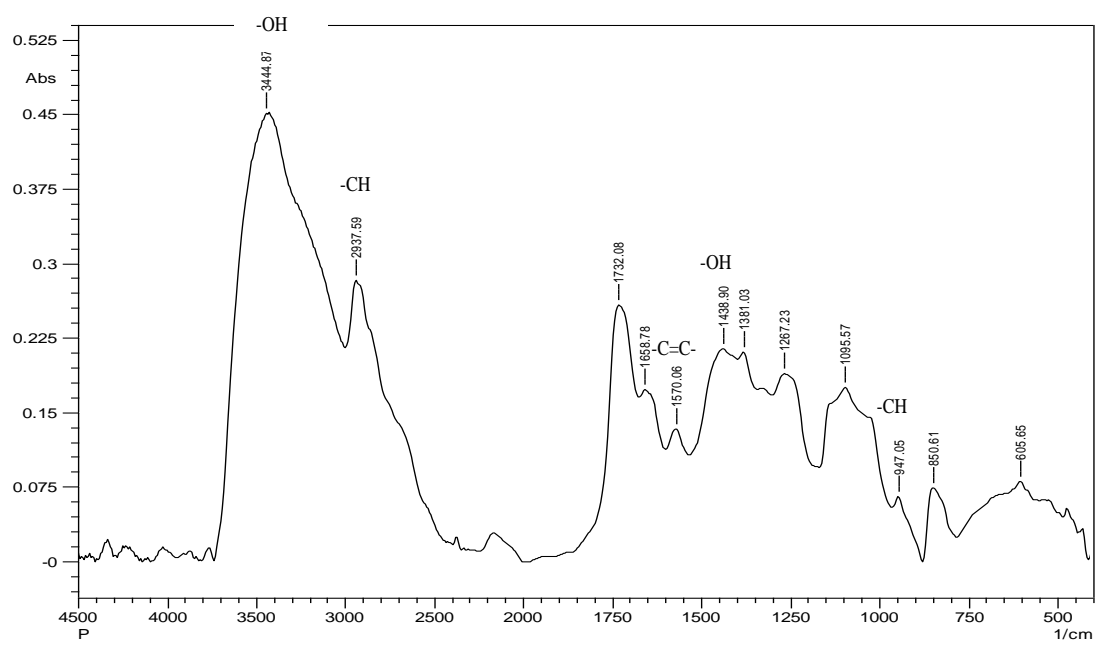

[b]

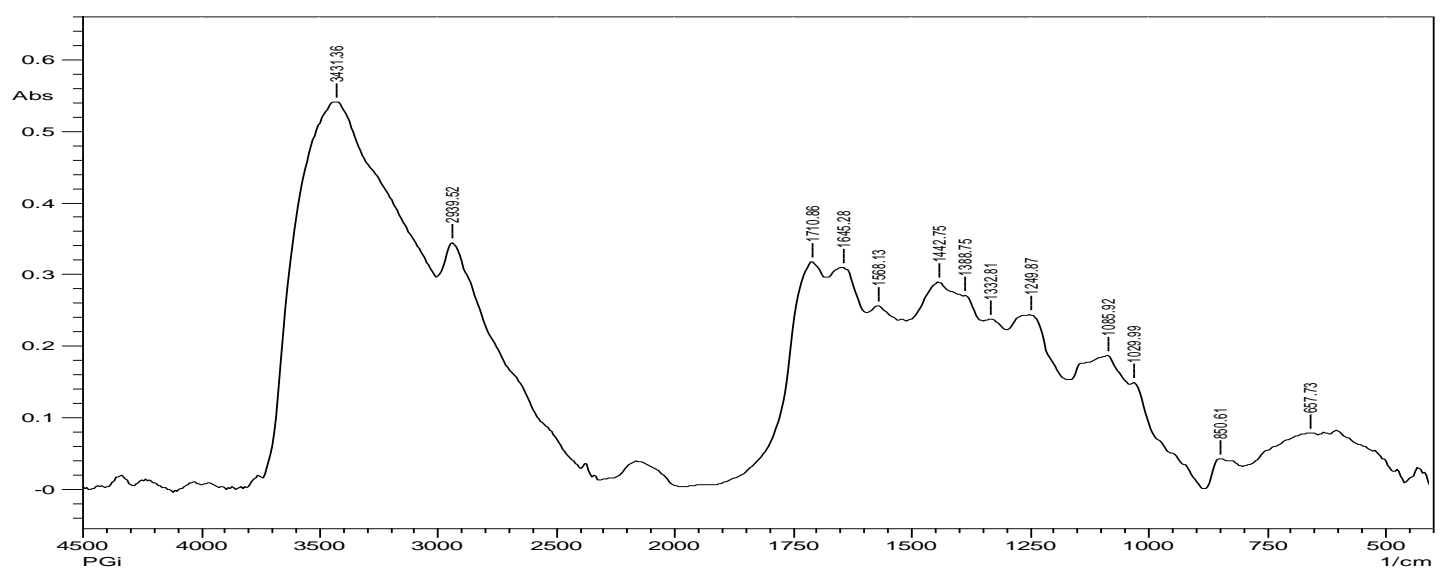

[c]

Gambar 7. Spektra FTIR [a] gelatin, [b] PVA, [c] PVA/gelatin

Tabel 2. Puncak serapan panjang gelombang PVA, Gelatin, Bacitracin, dan Neomycin

\begin{tabular}{|c|c|c|c|c|c|}
\hline Material & Absorpsi $\left(\mathrm{cm}^{-1}\right)$ & Gugus & Material & Absorpsi $\left(\mathrm{cm}^{-1}\right)$ & Gugus \\
\hline \multirow{7}{*}{ Gelatin } & $3600-3200$ & $\mathrm{O}-\mathrm{H}$ stretching & \multirow{7}{*}{ PVA } & & \\
\hline & $1420-1330$ & $\mathrm{O}-\mathrm{H}$ bending & & $1605-1466$ & $\mathrm{C}-\mathrm{C}$ \\
\hline & $2900-3000$ & $\mathrm{C}-\mathrm{H}$ stretching & & $2900-3000$ & $\mathrm{C}-\mathrm{H}$ stretching \\
\hline & $900-675$ & $\mathrm{C}-\mathrm{H}$ bending & & $900-675$ & $\mathrm{C}-\mathrm{H}$ bending \\
\hline & 1642 & $\mathrm{~N}-\mathrm{H}$ & & $3600-3200$ & $\mathrm{O}-\mathrm{H}$ stretching \\
\hline & $1605-1466$ & $\mathrm{C}-\mathrm{C}$ & & $1420-1330$ & $\mathrm{O}-\mathrm{H}$ bending \\
\hline & $1260-1000$ & $\mathrm{C}=\mathrm{O}$ & & & \\
\hline \multirow{9}{*}{ Bacitracin } & $3600-3200$ & $\mathrm{O}-\mathrm{H}$ stretching & \multirow{9}{*}{ Neomycin } & $3600-3200$ & $\mathrm{O}-\mathrm{H}$ stretching \\
\hline & $1420-1330$ & $\mathrm{O}-\mathrm{H}$ bending & & $1420-1330$ & $\mathrm{O}-\mathrm{H}$ bending \\
\hline & $3500-3100$ & $\mathrm{~N}-\mathrm{H}_{2}$ & & $3500-3100$ & $\mathrm{~N}-\mathrm{H}_{2}$ \\
\hline & $2900-3000$ & $\begin{array}{c}\text { pita uluran } \mathrm{C}-\mathrm{H} \\
\text { aromatik }\end{array}$ & & $2900-3000$ & $\begin{array}{c}\text { pita uluran } \mathrm{C}-\mathrm{H} \\
\text { aromatik }\end{array}$ \\
\hline & $1630-1642$ & $\mathrm{~N}-\mathrm{H}$ & & $1400-1600$ & gugus aromatik \\
\hline & $1400-1600$ & gugus aromatik & & $1000-1100$ & gugus aromatik \\
\hline & $1000-1100$ & gugus aromatik & & $1260-1000$ & $\mathrm{C}=\mathrm{O}$ \\
\hline & $1260-1000$ & $\mathrm{C}=\mathrm{O}$ & & $2900-3000$ & $\mathrm{C}-\mathrm{H}$ stretching \\
\hline & $2900-3000$ & $\mathrm{C}-\mathrm{H}$ stretching & & $600-900$ & $\mathrm{C}-\mathrm{H}$ stretching \\
\hline
\end{tabular}


Dari Gambar 7 dan Tabel 2 dapat dilihat puncak serapan dan gugus fungsi yang terdapat pada membran PVA/gelatin. Gugus-gugus yang terdapat pada PVA maupun gelatin merupakan gugus-gugus hidrofil, sehingga menjadikan kedua zat tersebut mudah larut dalam air. Dengan membandingkan spektra FTIR, terlihat bahwa spektra PVA/gelatin merupakan gabungan spektra PVA dan gelatin, sehingga dapat dikatakan bahwa membran serat nano tersebut memiliki kandungan senyawa organik dan struktur kimia yang sama dengan PVA dan gelatin. Hal ini terlihat pada Gambar 7c yang menunjukkan bahwa campuran PVA/gelatin juga memiliki puncak serapan yang sama dengan PVA dan gelatin pada panjang gelombang $3600-3200 \mathrm{~cm}^{-1}(\mathrm{O}-\mathrm{H}$ stretching); $1420-1330 \mathrm{~cm}^{-1}(\mathrm{O}-\mathrm{H}$ bending $) ; 3100-3000$ $\mathrm{cm}^{-1}$ (pita uluran $\mathrm{C}-\mathrm{H}$ aromatik); $1400-1600$ $\mathrm{cm}^{-1}$ dan $1000-1100 \mathrm{~cm}^{-1}$ (gugus aromatik); 1630 $-1642 \mathrm{~cm}^{-1}(\mathrm{~N}-\mathrm{H}) ; 1466-1605 \mathrm{~cm}^{-1}(\mathrm{C}=\mathrm{O})$; $2900-3000 \mathrm{~cm}^{-1}(\mathrm{C}-\mathrm{H}$ stretching $)$; dan $1260-$ $1000 \mathrm{~cm}^{-1}(\mathrm{C}=\mathrm{O})$.

Pada Gambar 8 disajikan spektra FTIR untuk Bacitracin, Neomycin, serta PVA/gelatin/ antibiotika topikal. Dengan membandingkan ketiga grafik spektra tersebut, maka dapat diketahui bahwa spektra tersebut adalah gabungan dari spektra PVA, gelatin, dan antibiotika topikal. Data ini menunjukkan keberadaan senyawa PVA, gelatin, Bacitracin, dan Neomycin pada larutan. Perlu dilakukan penelitian lebih lanjut untuk mengetahui apakah benar terjadi reaksi antara senyawa-senyawa tersebut atau hanya menunjukkan interaksi non kovalen antar senyawa saja.

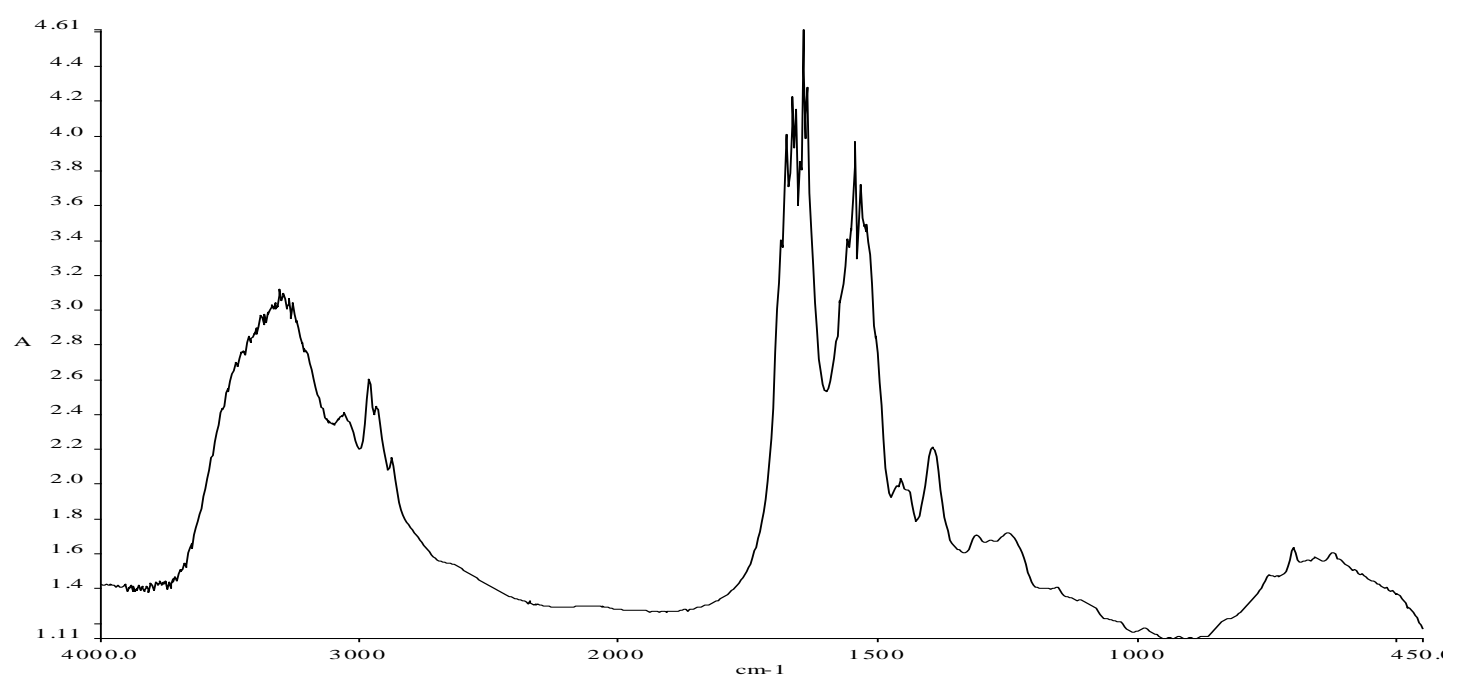

[a]

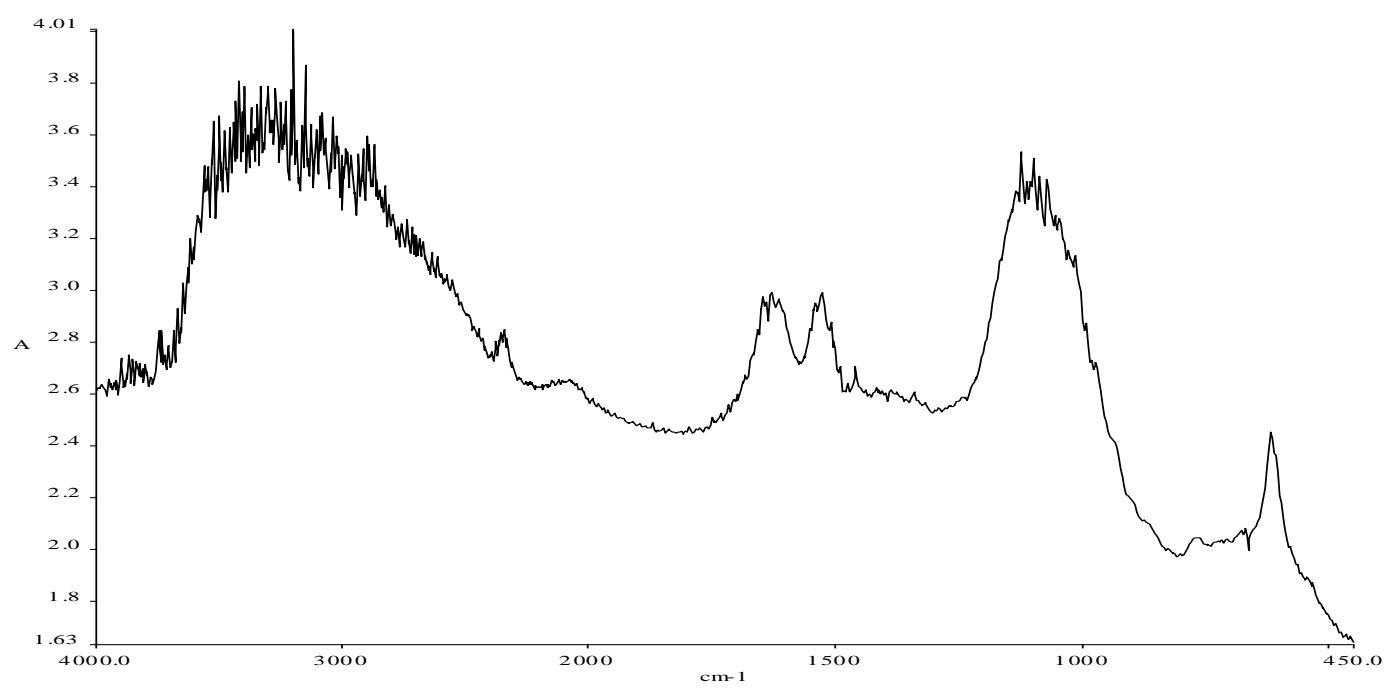

[b] 


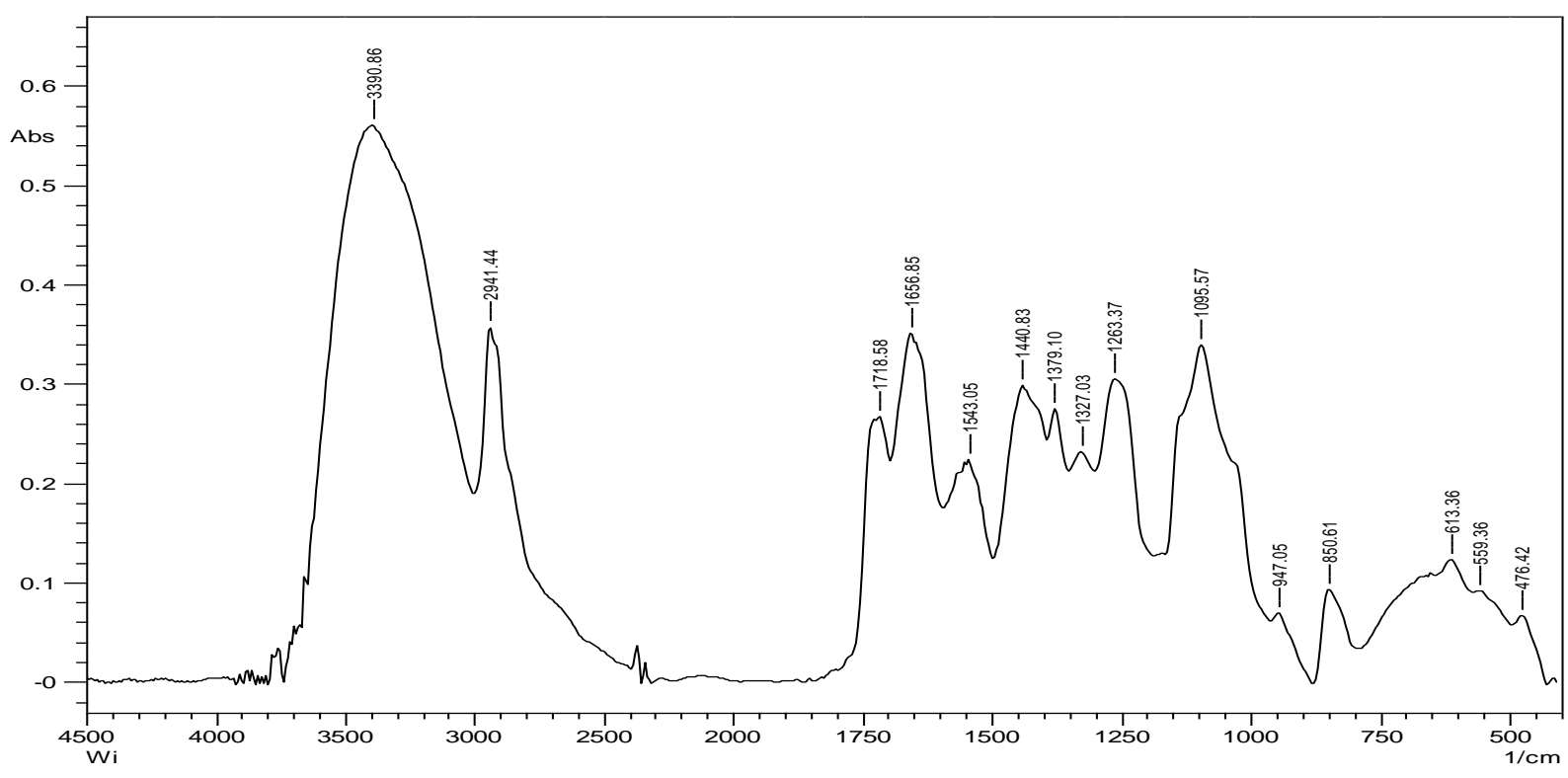

[c]

Gambar 8. Spektra FTIR [a] Bacitracin, [b] Neomycin, [c] PVA/gelatin/antibiotika topikal

\section{KESIMPULAN}

Electrospinning membran serat nano PVA/gelatin dan PVA/gelatin/antibiotika topikal telah berhasil dilakukan. Membran serat nano yang optimum diperoleh pada kondisi konsentrasi PVA $10 \%$ dan gelatin 5\% dengan rasio komposisi 70/30, terlihat dari karakternya yang memiliki lebih sedikit beads namun keseragaman serat paling baik. Pada kondisi tersebut diperoleh serat dengan rata-rata ukuran $\leq 300 \mathrm{~nm}$ dengan tingkat keseragaman dan distribusi serat yang cukup baik. Spektra FTIR menunjukkan keberadaan dan interaksi antar senyawa PVA, gelatin, Bacitracin, dan Neomycin pada larutan. Meski demikian, perlu dilakukan penelitian lebih lanjut untuk mengetahui apakah senyawa tersebut bereaksi satu sama lain atau hanya mengalami interaksi secara non kovalen. Untuk mengetahui efikasi membran serat nano PVA/gelatin/antibiotika topikal ini sebagai produk pembalut luka atau media penghantar obat, perlu dilakukan uji khasiat.

\section{PUSTAKA}

1. Formhals, A. (1934). Apparatus for producing artificial filaments from materials such as cellulose acetate. U.S. Patent 1975504.

2. Pillay, V., Dott, C., Choonara, E. Y., Tyagi, C., Tomar, L., Kumar, P., du Toit, L. C., Ndesendo, V. M. K. (2013). A Review of the Effect of Processing Variables on the Fabrication of Electrospun Nanofibers for Drug Delivery Applications. Journal of Nanomaterials. Volume 2013, Hindawi Publishing Corporation, 22 pages http://dx.doi.org/10.1155/2013/789289
3. Santos, C., Silva, C. J., Büttel, Z., Guimarães, R., Pereira, S. B., Tamagnini, P., \& Zille, A. (2014). Preparation and characterization of polysaccharides/PVA blend nanofibrous membranes by electrospinning method. Carbohydrate Polymers, 99, 584-592. doi:10.1016/j.carbpol.2013.09.008

4. Liu, Y., Wang, R., Ma, H., Hsiao, B. S., \& Chu, B. (2013). High-flux microfiltration filters based on electrospun polyvinylalcohol nanofibrous membranes. Polymer, 54(2), 548 56. doi:10.1016/j.polymer.2012.11.064

5. Loh, X. J., Peh, P., Liao, S., Sng, C., \& Li, J. (2010). Controlled drug release from biodegradable thermoresponsive physical hydrogel nanofibers. Journal of Controlled Release, 143(2), 175182. doi:10.1016/j.jconrel.2009.12.030

6. Bhardwaj, N., \& Kundu, S. C. (2010). Electrospinning: A fascinating fiber fabrication technique. Biotechnology Advances, $\quad 28(3), \quad 325-$ 347. doi:10.1016/j.biotechadv.2010.01.004

7. Laha, A., Sharma, C. S., \& Majumdar, S. (2016). Electrospun gelatin nanofibers as drug carrier: effect of crosslinking on sustained release. Materials Today: Proceedings, 3(10), 3484-3491. doi:10.1016/j.matpr.2016.10.031

8. Gautam, S., Dinda, A. K., \& Mishra, N. C. (2013). Fabrication and characterization of PCL/gelatin composite nanofibrous scaffold for tissue engineering applications by electrospinning method. Materials Science and 
Engineering: $\quad C, \quad 33(3), \quad 1228$ 1235. doi:10.1016/j.msec.2012.12.015

9. Li, D., Chen, W., Sun, B., Li, H., Wu, T., Ke, Q., Mo, X. (2016). A comparison of nanoscale and multiscale PCL/gelatin scaffolds prepared by disc-electrospinning. Colloids and Surfaces B: Biointerfaces, 146, 632641. doi:10.1016/j.colsurfb.2016.07.009

10. Correia, T. R., Ferreira, P., Vaz, R., Alves, P., Figueiredo, M. M., Correia, I. J., \& Coimbra, P. (2016). Development of UV cross-linked gelatin coated electrospun poly(caprolactone) fibrous scaffolds for tissue engineering. International Journal of Biological Macromolecules, $\quad 93, \quad 1539$ 1548. doi:10.1016/j.ijbiomac.2016.05.045

11. Xue, J., He, M., Liu, H., Niu, Y., Crawford, A., Coates, P. D., Zhang, L. (2014). Drug loaded homogeneous electrospun PCL/gelatin hybrid nanofiber structures for anti-infective tissue regeneration membranes. Biomaterials, 35(34), 9395-

9405. doi:10.1016/j.biomaterials.2014.07.060

12. Yang, D., Li, Y., \& Nie, J. (2007). Preparation of gelatin/PVA nanofibers and their potential application in controlled release of drugs. Carbohydrate Polymers, 69(3), 538 543. doi:10.1016/j.carbpol.2007.01.008

13. Laha, A., Yadav, S., Majumdar, S., \& Sharma, C. S. (2016). In-vitro release study of hydrophobic drug using electrospun crosslinked gelatin nanofibers. Biochemical Engineering Journal, 105, 481488. doi:10.1016/j.bej.2015.11.001

14. Merkle, V. M., Tran, P. L., Hutchinson, M., Ammann, K. R., DeCook, K., Wu, X., \& Slepian, M. J. (2015). Core-shell PVA/gelatin electrospun nanofibers promote human umbilical vein endothelial cell and smooth muscle cell proliferation and migration. Acta Biomaterialia, $\quad 27, \quad 77-$ 87. doi:10.1016/j.actbio.2015.08.044

15. Morsy, R., Hosny, M., Reicha, F., \& Elnimr, T. (2017). Developing and physicochemical evaluation of cross-linked electrospun gelatinglycerol nanofibrous membranes for medical applications. Journal of Molecular Structure, 1135 , $222-$

227. doi:10.1016/j.molstruc.2017.01.064

16. Rath, G., Hussain, T., Chauhan, G., Garg, T., \& Goyal, A. K. (2016). Development and characterization of cefazolin loaded zinc oxide nanoparticles composite gelatin nanofiber mats for postoperative surgical wounds. Materials
Science and Engineering: C, 58, 242253. doi:10.1016/j.msec.2015.08.050

17. Sanaei-rad, P., Jafarzadeh Kashi, T., Seyedjafari, E., \& Soleimani, M. (2016). Enhancement of stem cell differentiation to osteogenic lineage on hydroxyapatite-coated hybrid PLGA/gelatin nanofiber scaffolds. Biologicals, 44(6), 511516. doi:10.1016/j.biologicals.2016.09.002

18. Meng, Z. X., Wang, Y. S., Ma, C., Zheng, W., Li, L., \& Zheng, Y. F. (2010). Electrospinning of PLGA/gelatin randomly-oriented and aligned nanofibers as potential scaffold in tissue engineering. Materials Science and Engineering: $\quad C, \quad 30(8), \quad 1204-$ 1210. doi:10.1016/j.msec.2010.06.018

19. Meng, Z. X., Xu, X. X., Zheng, W., Zhou, H. M., Li, L., Zheng, Y. F., \& Lou, X. (2011). Preparation and characterization of electrospun PLGA/gelatin nanofibers as a potential drug delivery system. Colloids and Surfaces B: Biointerfaces, 84(1), 97102. doi:10.1016/j.colsurfb.2010.12.022

20. Ratanavaraporn, J., Rangkupan, R., Jeeratawatchai, H., Kanokpanont, S., \& Damrongsakkul, S. (2010). Influences of physical and chemical crosslinking techniques on electrospun type $A$ and $B$ gelatin fiber mats. International Journal of Biological Macromolecules, 47(4), 431438. doi:10.1016/j.ijbiomac.2010.06.008

21. Okutan, N., Terzi, P., \& Altay, F. (2014). Affecting parameters on electrospinning process and characterization of electrospun gelatin nanofibers. Food Hydrocolloids, 39, 19-26. doi:10.1016/j.foodhyd.2013.12.022

22. Mutia, T., Eriningsih, R., (2012). Penggunaan Webs Serat Alginat Hasil Proses Electrospinning Untuk Pembalut Luka Primer, Jurnal Riset Industri, Jakarta, Vol. VI, No. 2.

23. Mutia, T., Eriningsih, R., Safitri, R., (2013). Serat Nano Gelatin/Polivinil Alkohol Untuk Keperluan Tekstil Medis, Jurnal Riset Industri, Jakarta, Vol. VII, No. 3.

24. Mutia, T., dan Moeliono, M., (2014). Webs Serat Nano Alginat/Polivinil Alkohol Untuk Media Penyampaian Obat Topikal, Jurnal Riset Industri, Volume 8, No. 3, Desember.

25. Schiffman, J. D., \& Schauer, C. L. (2008). A review: Electrospinning of biopolymer nanofibers and their applications. Polymer Reviews, 48(2), 317-352. 
26. Bonino, C. A., Krebs, M. D., Saquing, C. D., Jeong, S. I., Shearer, K. L., Alsberg, E., et al. (2011). Electrospinning alginate-based nanofibers: From blends to crosslinked low molecular weight alginate-only systems. Carbohydrate Polymers, 85(1), 111-119.

27. Fan, L., Yang, H., Yang, J., Peng, M., \& Hu, J. (2016). Preparation and characterization of chitosan/gelatin/PVA hydrogel for wound dressings. Carbohydrate Polymers, 146, 427434. doi:10.1016/j.carbpol.2016.03.002

28. Choi, Y. H., Seung, S. C., Simkhada, J. R., Rahman, Md, S., Yoon, S. C., Chun, S. K., Jin, C. Y., (2017). A Novel Multifunctional Peptide Oligomer of Bacitracin with Possible Bioindustrial and Therapeutic Applications from a Korean Food-Source Bacillus Strain, PLoS One, https://doi.org/10.1371/journal.pone.0176971

29. Chang, J., June, C., Yoon, C. R., Myung, H. Y., Kyoung, H. O., Gi, J. I., Seung, H. L., Soon, Y. K., Park, H., Sung, W. C., Jung, H. K., (2016). Sodium Selenite Acts as an Otoprotectant against Neomycin-Induced Hair Cell Damage in a Zebrafish Model, PLoS One, Published: March 14, https://doi.org/10.1371/journal.pone.0151557

30. Anonimous, (2008). Informasi Spesialite Obat Indonesia, Ikatan Sarjana Farmasi Indonesia.
31. Panboon, MSS, (2000). Electro-spinning of Polyvinyl Alcohol/Chitosan Fibers for Wound Dressing Application, King Mongkut's Institute of Technology North Bangkong.

32. Peter PT, et. all., (2004). Investigation of Fiber, Bulk and Surface Properties of Meltblown and Electrospun Polymeric Fabrics, Textile and nonwoven Development Center, INJ Fall.

33. Edward, JV, et.al., (2006). The Future of Modified Fibers, Southern Regional Research Center, New Orleans.

34. Brown, PJ, et.al., (2007). Nanofibers and Nanotechnology in Textiles, The Textile Institute, Woodhead Pub. Ltd., Cambridge.

35. Mutia, T., Safitri, R., Eriningsih, R., (2011). Membran Alginat Sebagai Pembalut Luka Primer dan Media Penyampaian Obat Topikal Untuk Luka Terinfeksi, Jurnal Riset Industri, Jakarta, Vol. V, No. 2.

36. Nuanchan, C, et.al., (2007). Electrospun Gelatin Fibers: Effect of Solvent System on Morphology and Fibers Diameters, Polymer J., Vo. 39., No. 6., pp 622-631.

37. Silverstein, RM, et. al., (1975). Spectrometric Identification of Organic Compound, Third Edition, John Willey \& Sons, New York. 
Arena Tekstil Vol. 35 No. 2, 2020 : 95-106 